\title{
The Impact of Delays of Freight Trains in JIT System on Example One Track Line
}

\author{
Matúš Dlugoš ${ }^{1, *}$, Lumír Pečený ${ }^{1}$, Pavol Meško ${ }^{1}$, and Peter Šulko ${ }^{2}$ \\ ${ }^{1}$ University of Žilina, Faculty of Operation and Economics of Transport and Communications, \\ Department of Railway Transport, Univerzitná 8215/1, 01026 Žilina, Slovakia \\ ${ }^{2}$ Železnice Slovenskej republiky (ŽSR), Klemensová 8, 81361 Bratislava, Slovak Republic
}

\begin{abstract}
The paper describes the problem between freight trains operated by Metrans Danube, a.s. and passenger trains operated by Regiojet, a.s on the line Bratislava - Dunajská Streda - Komárno. It is very important to emphasize this problem because, nowadays, mostly freight trains across the Europe drive in just in time system, it means, that shipments are delivered at exact time and place on time. At this line there are many problems not only this track line is single track, so it is necessary to cross the trains very often in traffic points which maximum 2 traffic tracks but also organizing of transport is more complicated which is provided by Railway infrastructure manager - this case is very important example when railway traffic technology slows down all processes in the logistic chain.
\end{abstract}

\section{Introduction}

Railway line Bratislava - Dunajská Streda - Komárno, marked in timetable 131, connected cities Bratislava - Dunajská Streda - Komárno. It is $100 \mathrm{~km}$ long single track with gauged $1435 \mathrm{~mm}$. The maximum speed limit is $80 \mathrm{kph}$. The object of the track is situated in an unpretentious terrain in region Žitný ostrov. Maximum inclination is 5\% and category of line class is D4. Organizing and transport service is provided from the center of operating point in Dunajská Streda. They operated transport from Komárno st. 4 (without) to Bratislava-Nové Mesto (without) [1].

There was an extensive reconstruction between Podunajské Biskupice - Dunajská Streda in 2011 [2].

* Corresponding author: matus.dlugos@fpedas.uniza.sk 


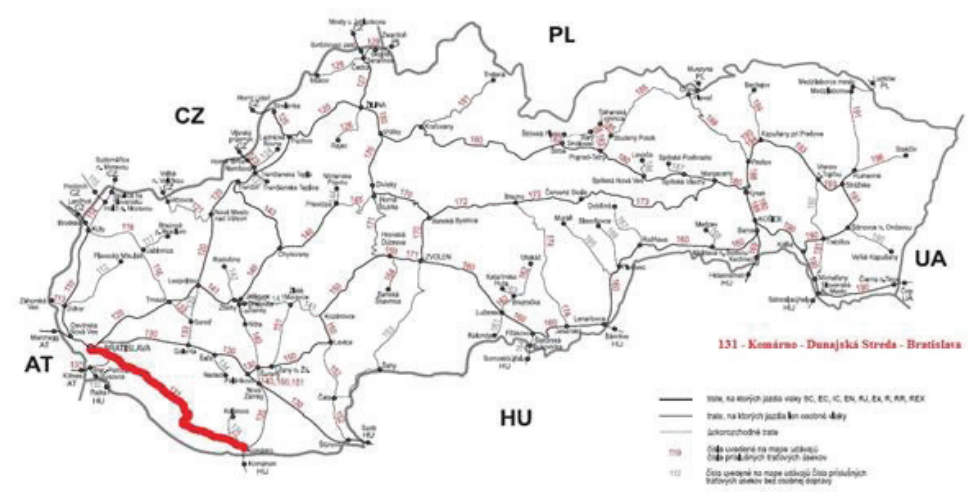

Fig. 1. Track 131 marked in the scheme of ŽSR railways. Source [2]

\section{Contemporary operators}

At present, both - the passenger trains and freight trains are operated at this line. By the end of 2011, personal transport was provided by ZSSK which transported about 790000 passengers a year. From the March of 2012, the private passenger operator RegioJet started to operate passenger transport. The act was signed in December 2010 but valid from March 2012 to December 2020. Until this day, the number of transported passengers is about 1,412 mil. from the beginning 2017. The number of passenger trains is growing and nowadays is the operated periodic timetable with half an hour period in the peak hour.

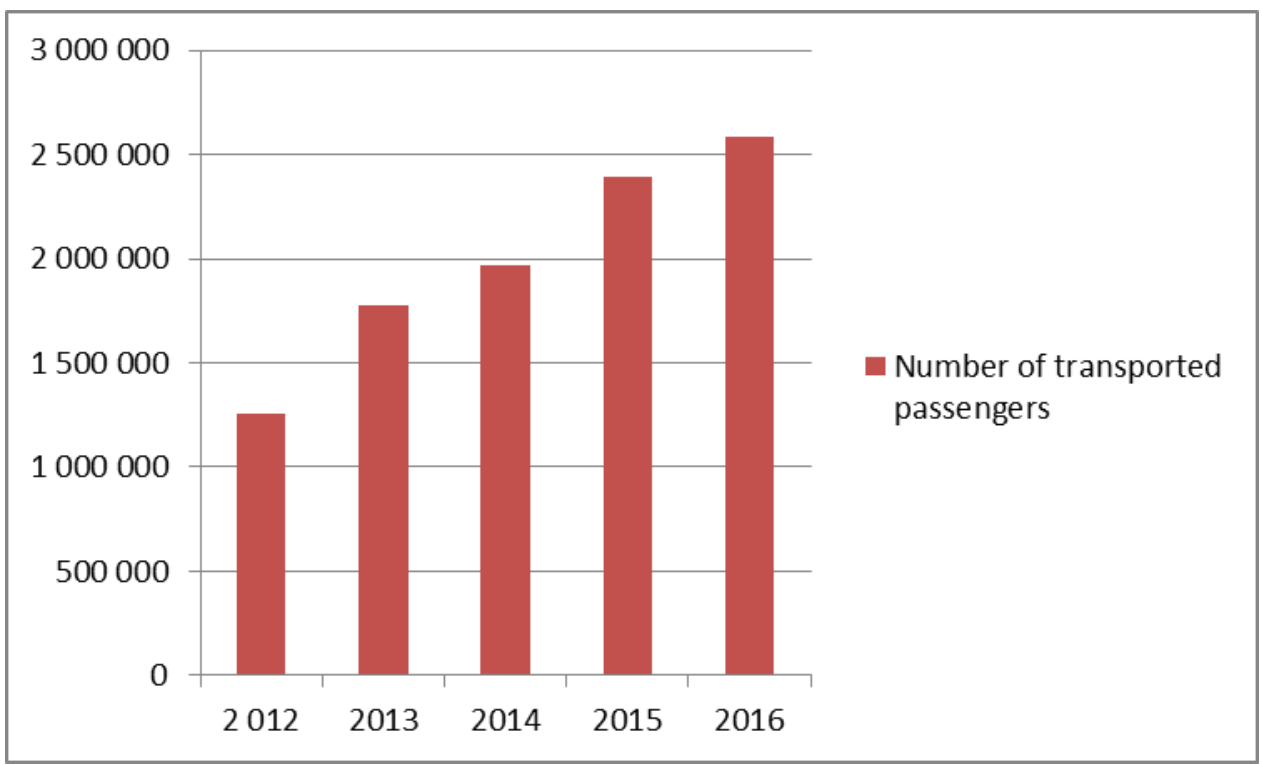

Fig. 2. The graph of transported passengers by RegioJet. Source [1]

Freight operator Metrans Danubia provides and operates terminal of intermodal transport in Dunajská Streda. They transport containers and exchange superstructures from the terminal to the other terminals around the Europe, for example to Koper or Trieste. [3]. 
Their trains drive in just in time system, so it is very important to keep the time of arriving in terminals. On avarage 8-9 trains daily leave the terminal from Dunajská Streda to the others.

The last one, state freight operator ZSSK CARGO, provides mainly transport cereals. They load the wagons in stations on the track to Komárno. They only provide handling trains, there [4].

\section{JIT system}

As we mentioned, the Just In Time technology or Just In Time system is the most widespread logistics system in the field of supplies, manufacturing and distribution. In the field of transport, JIT system means to distribute or deliver shipments from one terminal, stations or ports to the other on time, to reduce storage costs, efectivelly save storage place, decrease the number of train requirements, which includes number of employees locomotive drivers, shifters and in the end increase efficient use of them [5].

In addition, JIT technology is required:

-shorter and more reliable shipping time,

-more sophisticated communication,

-fewer carriers with long-term relationships,

-efficiently designed conveying means and material handling equipment,

-quality decision models on the use of means of transport (own, public, contract) [6].

\section{The reasons that affect the origination of the train delays}

Due to the fact the mentioned track is single track line, the number of trains is from year to year higher and the capacity is already exhausted. It is mainly caused by passenger trains which are ordered by Ministry of Transportation of Slovak Republic, however the package of vlkm is every year the same. Not only passenger trains are the biggest problem. There are also the other reasons why it is complicated to provide freight trains of Metrans company don't drive on time but usually delay.

We can divide reasons of delay due their origination:

-First group is formed by the effects caused by infrastructure,

- secondone is caused by problems on the side of operators,

-lastone is formed by problems caused by third side [7].

\subsection{Effects caused by infrastructure}

There are many reasons and problems, why it is complicated to provide trains on this track. At first, there is a problem with the capacity. As a single track with no trackside security equipment, trains drive from one station to the next station. Between some stations there is an automatic block signal, that divides interstationary section into 2 block sections, it is situated mainly between stations which are in a large distance [8].

Another reason is that some of the railway stations have only 2 traffic rails to cross the trains, for example station Lehnice. It isn't possible to cross more than 2 trains. Closely linked with the stations are self-resetting switches. It means that trains from the one direction drive only to the branch by $40 \mathrm{kph}$. The lenght of traffic rails is also problem, mainly for freight trains of Metrans, because usually it is a problem to cross passenger train with freight train [9]. 
The speed limit is also problem, track is built in a very flat terrain and they drive only $80 \mathrm{kph}[1]$.

LEHNICE

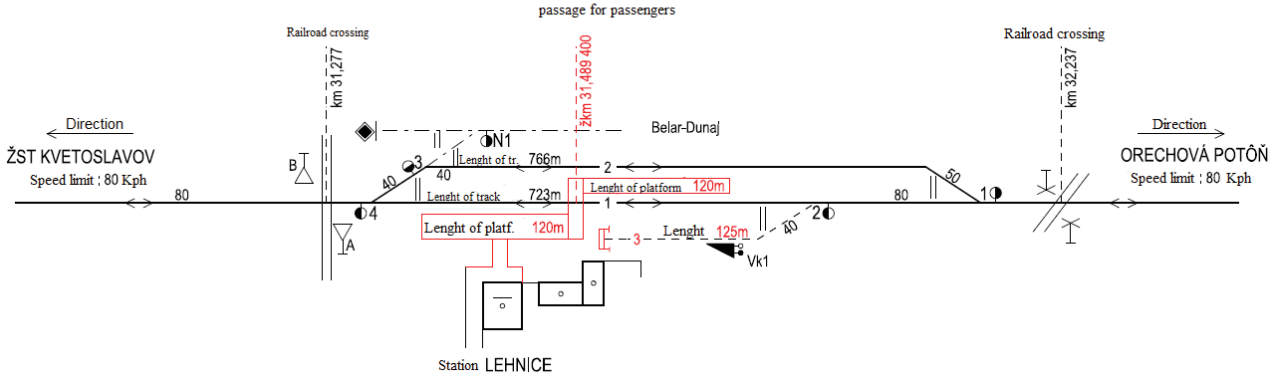

Fig. 3. Scheme of railway station Lehnice. Source [2]

\subsection{Effects on the side of operators}

In the actual train traffic diagram 2016/2017 there are 27 passenger trains from Bratislava to Dunajská Streda (Komárno) and 30 trains to Bratislava operated by Regiojet. Except of this 2 pairs of trains are operated as regional express situated during the rush hours, when many trains is necessary to cross very often [10].

For example in the morning hours, there is a passenger train 4315 from Bratislava to Komárno, it leaves at 8:05 and arrives 10:13 and during the journey it crosses 7 times. The intersection interval is too much short, so if the opposite train is delayed for more than 5 minutes, it disrupts the whole traffic diagram and passenger trains are delayed the whole day, because the time to turnover the rolling stock is short in final station, so final delay time may change $[11,12]$.

The another problem seems to be in connections. Some of the passenger trains from Komárno or Dunajská Streda are connections to Regiojet trains to Prague and in reverse.

The most common problem is train failure, it is cause mainly by the old types of rolling stocks or insufficient quality of service.

Operator Metrans Danubia provides intermodal transport of containers across Europe. The most common destinations are port Koper, Trieste, Marien St. Lorenzen, Budapest, Česká Třebová or Haniska pri Košiciach (Slovakia) [12, 13].

The majority of these places are so far, so there is a very high risk that it could delay why it is necessary to communicate with other international operators and make a deal how to solve the problems to avoid a delay. The most common problems are damaged wagons or broken trains and then If train is delay, it will affect the turnovers of wagons and locomotives and furthermore it can cause that train will stop there longer, because it didn't come on time and actually other operator can manipulate in terminal [14-16] 


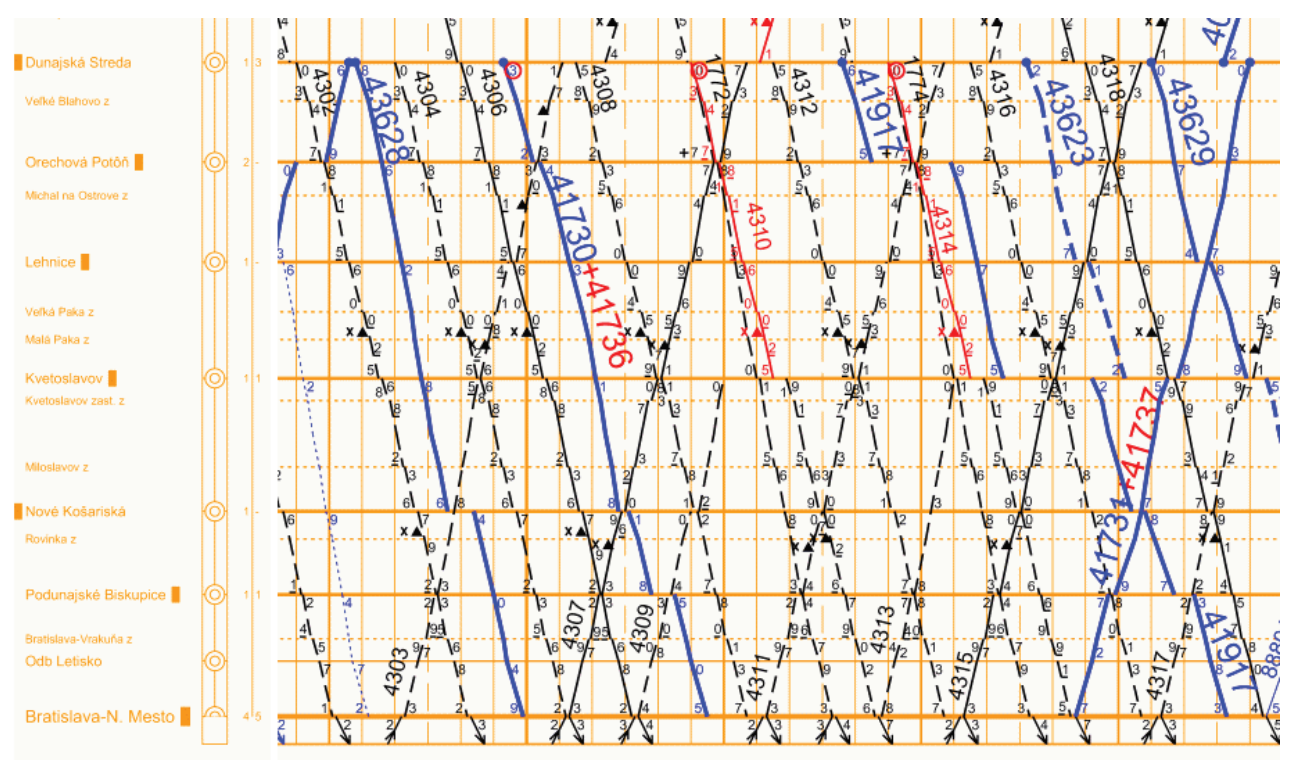

Fig. 4. Part of the train traffic diagram with passenger and freight trains between Bratislava Dunajská Streda. Source [2]

\subsection{Effects caused by third side}

Effects caused by third side are connected mainly with things which operators can't influence, for example, bad weather, traffic accident on the road when the trucks drive to terminal with containers or custom officer stop the trains and check the papers $[17,18]$.

\section{Conclusion}

The basic problem of this line is that it is singletrack. There isn't enough capacity so there will be more problems in the future how to provide personal and freight trains, because year to year the amount of passengers is higher and the operator Regiojet wants to add other trains. Also Metrans is forced to make a shorter trainsets because of lenght of rails in stations what causes that they break a trainset in two pieces and drive more than it's necessary and it causes delay.

Another option is to build second track but this responsibility is for manager of railway infrastructure - ŽSR. This aim should be a part of the state policy. Nowadays the railway infrastructure manager also Ministry of Transport don't have an action plan how solve this situation.

This paper is supported by the VEGA Project 1/0095/16 'Assessment of the quality of connections on the transport network as a tool to enhance the competitiveness of public passenger transport system, that is solved at Faculty of Operations and Economics of Transport and Communication, University of Žilina.

This paper is supported by the research project "From horse-drawn railway to intermodal transport" within Visegrad Fund. 


\section{References}

1. G. Fedorko, V. Molnár, J. Strohmandl, M. Vasil', Transport Means 2015 - 19th international scientific conference, 466-469 (Kaunas University of Technology, Lithuania, 2015)

2. H. Neradilova, G. Fedorko, Open Engineering 6, 700-710 (2016), DOI:10.1515/eng2016-0085

3. I. Kubaskova, M. Šulgan, Logistics for forwarders and road transport (in slovak), 229 p. (University of Zilina, Slovak Republic, 2013)

4. Internal documents of Manager of Infrastructure - ŽSR (2017)

5. J. Danis, A. Dolinayova, J. Camaj, PRTDSR, ESM 2016 - the 2016 international conference on Engineering science and management, 187-190 (Advances in engineering research 62, Zhengzhou, Henan, China, 2016)

6. J. Gasparik, B. Abramovic, M. Halas, Promet-Traffic and Transportation, 283-290 (2015)

7. J. Gasparik, V. Zitricky, Transport 25, 4, 387-393 (2010), DOI: 10.3846/transport.2010.48

8. L. Černá, A. Dolinayová, J. Daniš, Transport means 2016 - 20th international scientific conference, 414-419 (Juodkrante, Lithuania, 2016)

9. L. Černá, V. Zitrický, J.Daniš, Open Engineering 7, 1, 6-13 (2017)

10. M. Dlugos, Optimalizácia obehu vlakových súprav RegioJet, a.s. na trati Komárno Dunajská Streda - Bratislava hl. st. (Diploma thesis, University of Zilina, Slovak Republic, 2017)

11. M. Kendra, P. Šulko, M. Babin, BulTrans-2013 - Anniversary scientific conference on aeroanutics, automative and railway engineering and technologies, 95-97 (Sofia, Bulgaria, 2013)

12. V. Gaborova, L. Peceny, J. Gasparik, ICTTE - 3rd International Conference on Traffic and Transport Engineering, 462-466 (Belgrade, Serbia, 2016)

13. V. Zitricky, L. Černá, B. Abramovic, 12th International Scientific Conference of Young Scientists on Sustainable, Modern and Safe Transport, 994-999 (Procedia Engineering, High Tatras, Slovakia, 2017)

14. O. Stopka, J. Ponický, M. Chovancová, V. Zitrický, Nase More 63, 3, 200-203 (2016), DOI: $10.17818 / \mathrm{NM} / 2016 / \mathrm{SI} 23$

15. J. Lalinská, J. Gašparík, D. Šipuš, Logi - Scientific Journal on Transport and Logistics 8, 1, 74-81 (2017), DOI:10.1515/logi-2017-0009

16. Z. Zahumenska, J. Gasparik, 12th International scientific conference of young scientists on sustainable, modern and safe transport, 976-981 (Procedia engineering, High Tatras, Slovakia, 2017)

17. V. Zitricky, P. Šulko, LOGI 2014 - 15th international scientific conference, 377-384 (Pardubice, Czech Republic, 2014)

18. K. Koštálová, Logi - Scientific Journal on Transport and Logistics 2, 2, 38-47 (2011) 